\title{
Angiotensin II Type 1 Receptor (AT-1R) Expression Correlates with VEGF-A and VEGF-D Expression in Invasive Ductal Breast Cancer
}

\author{
Aleksandra Jethon • Bartosz Pula • \\ Aleksandra Piotrowska • Andrzej Wojnar • \\ Janusz Rys • Piotr Dziegiel • \\ Marzena Podhorska-Okolow
}

Received: 11 August 2011 / Accepted: 5 March 2012 /Published online: 12 May 2012

(C) The Author(s) 2012. This article is published with open access at Springerlink.com

\begin{abstract}
Recent studies point to the involvement of angiotensin II (Ang II) receptor type 1 (AT-1R) on processes of metastasing, stimulation of invasiveness and angiogenesis in tumours. In this study, the correlation between intensity of AT-1R expression and expression of lymph- and angiogenesis markers in invasive ductal breast cancers (IDC) was examined. Immunohistochemical studies (IHC) were performed on archival material of 102 IDC cases. Only 28 (27.5\%) cases manifested low AT-1R expression while 74 (72.5\%) cases demonstrated a moderate or pronounced AT$1 \mathrm{R}$ expression. Expression intensity of AT-1R was found to correlate with expressions of VEGF-A $(r=0.26 ; p=0.008)$ and VEGF-D $(r=0.24 ; p=0.015)$. Out of the examined markers of angiogenesis and lymphangiogenesis only the pronounced expression of VEGF-C was found to correlate
\end{abstract}

\footnotetext{
A. Jethon $\cdot$ B. Pula $\cdot$ A. Piotrowska $\cdot$ P. Dziegiel $\cdot$

M. Podhorska-Okolow $(\square)$

Department of Histology and Embryology, Medical University, Chalubinskiego 6a, 50-368,

Wroclaw, Poland

e-mail: marzenna.podhorska-okolow@am.wroc.pl
}

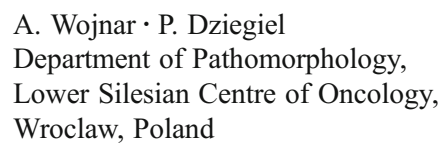

with patient poor clinical outcome $(p=0.009)$. The positive correlation between AT-1R and VEGF-A and VEGF-D could point to stimulatory action of Ang II on their expression what might result in augmented lymph- and angiogenesis in IDC.

Keywords Angiotensin receptors · VEGF · Angiogenesis · Lymphangiogenesis $\cdot$ Breast cancer

\section{Introduction}

Breast cancer is the most frequent female malignancy all over the world. In 2008 its incidence was appraised at 1.38 million new cases ( $23 \%$ of all tumours) with increasing frequency of its manifestation $[1,2]$.

Angiotensin II (Ang II) represents an important element of renin-angiotensin system (RAS). It is a multifunctional octapeptide, formed by excision of two amino acids (histidine and leucine) from carbonyl terminus of its precursor, angiotensin I. The reaction is executed by angiotensin converting enzyme (ACE), secreted mainly by the endothelium of pulmonary blood vessels [3]. Ang II acts via two types of receptors, AT-1R and AT-2R, which are coupled to G proteins [4]. Ang II stimulates the release of aldosteron, vasopressin and nitrogen oxide. It is involved in the development of oxidative stress, inflammatory processes, maintenance of an appropriate level of body electrolytes and water, in blood vessel remodelling, processes of vascular atherogenesis and it stimulates the contraction of vascular myocytes [5-7]. Expression of AT-1R was demonstrated in cells of several organs [8]. On the other hand, angiotensin type 2 receptor (AT-2R), responsible, i.a., for induction of apoptosis, is less 
common and expressed mainly in fetal cells. In an adult healthy organism, it is expressed in cells of vascular endothelium, uterine muscle, ovaries, some cerebral structures and in selected structures of skin, kidneys, heart $[9,10]$.

Several earlier studies pointed to a significant function of Ang II on several aspects of neoplastic disease and compounds suppressing action of Ang II were suggested to have an anti-neoplastic significance [11]. Overexpression of AT$1 \mathrm{R}$ was observed in many types of tumours including tumours of pancreas, kidneys and lungs [12-14].

In mammary gland, presence of both receptor types was demonstrated [8]. AT-1R is located in epithelial cells of alveoli and lactiferous ducts, both in the healthy tissue and in benign tumours (15). Increased levels of AT-1R mRNA were observed in hyperplastic lesions, in ductal breast cancer in situ (DCIS) and in IDC [16]. AT-1R activation by Ang II resulted in proliferation of breast cancer cells [7, 17]. In cases of metastazing IDC only a weak cytoplasmic expression of AT-1R was demonstrated [6]. The till now performed studies showed also that breast cancer cells may acquire metastazing ability i.a. due to changes in activity and accessibility of Ang II in the pathway linked to AT-1R [18, 19]. It was also shown that blockade of AT-1R decreased invasiveness of tumour cells [20]. No such effect was shown in the case of AT-2R. The results of the studies mentioned above point to a potential of applying AT-1R blockers in antineoplastic therapy [19].

Ang II is also engaged in the process of angiogenesis, of key importance from the point of view of neoplastic progression $[21,22]$. In numerous studies stimulatory effect of Ang II on the formation of new blood vessels was shown [23]. Moreover, blockade of ACE and AT-1R significantly inhibited development of many tumour types (breast cancer, non-small cell pulmonary cancer, gastric cancer) and decreased the density of blood vessels as well as their metastatic potential [12, 24]. In the case of tumour lymphangiogenesis no data are currently available on the involvement of Ang II.

In this study, we undertook an attempt to define the significance of AT-1R expression, with particular attention paid to its correlation with selected markers of angiogenesis (CD31, VEGF-A) and lymphangiogenesis (D2-40, Lyve-1, VEGF-C and VEGF-D) in IDC.

\section{Material and Methods}

Patients

The studies were conducted on archival paraffin blocks of IDC subjected to radical surgery in 1999-2002 in the Lower Silesia Centre of Oncology in Wroclaw. Clinical and pathological data were obtained from hospital archives. A group of 102 patients, aged between 30 and 83 years (mean of
56 years) was retrospectively analyzed. Duration of observation ranged between 1 and 125 months (mean of 61 months). The clinical and pathological data are summarized in Table 1.

Immunohistochemistry (IHC)

Immunohistochemical reactions were performed on paraffin sections using DAKO Autostainer Link48 (Dako, Glostrup, Denmark) in case of the following antibodies in respective concentrations: mouse anti-AT-1R $(24.7 \mu \mathrm{g} / \mathrm{ml}$; Abcam, Cambridge, UK), mouse anti-CD31 $(0.69 \mu \mathrm{g} / \mathrm{ml}$; Leica Microsystems, Wetzlar, Germany), mouse anti-D2-40 (RTU; Dako), mouse anti-VEGF-A $(1 \mu \mathrm{g} / \mathrm{ml}$; Dako) and mouse anti-Ki-67 (clone MIB-1, $0.8 \mu \mathrm{g} / \mathrm{ml}$; Dako). In order

Table 1 Clinical and pathological data of 102 studied cases of IDC

\begin{tabular}{|c|c|c|}
\hline Parameter & Number of cases & $\%$ \\
\hline \multicolumn{3}{|c|}{ Patient's age } \\
\hline$\leq 50$ & 35 & 34.3 \\
\hline$>50$ & 67 & 65.7 \\
\hline \multicolumn{3}{|l|}{ Menopause } \\
\hline Pre & 38 & 37.3 \\
\hline Post & 64 & 62.7 \\
\hline \multicolumn{3}{|c|}{ Tumour size } \\
\hline$\leq 2 \mathrm{~cm}$ & 64 & 62.7 \\
\hline$>2 \mathrm{~cm}$ & 38 & 37.3 \\
\hline \multicolumn{3}{|c|}{ Grade of malignancy } \\
\hline G1 & 10 & 9.8 \\
\hline G2 & 57 & 55.9 \\
\hline G3 & 35 & 34.3 \\
\hline \multicolumn{3}{|l|}{$\mathrm{pT}$} \\
\hline 1 & 59 & 57.8 \\
\hline 2 & 32 & 31.5 \\
\hline 3 & 8 & 7.8 \\
\hline 4 & 3 & 2.9 \\
\hline \multicolumn{3}{|l|}{$\mathrm{pN}$} \\
\hline pN0 & 52 & 51 \\
\hline pN1-3 & 50 & 49 \\
\hline \multicolumn{3}{|l|}{ ER } \\
\hline Positive & 81 & 79.4 \\
\hline Negative & 21 & 20.6 \\
\hline \multicolumn{3}{|l|}{ PR } \\
\hline Positive & 68 & 66.7 \\
\hline Negative & 34 & 33.3 \\
\hline \multicolumn{3}{|c|}{ HER2 (IHC) } \\
\hline Positive & 15 & 14.7 \\
\hline Negative & 87 & 85.3 \\
\hline \multicolumn{3}{|l|}{$\mathrm{Ki}-67$} \\
\hline$\leq 25 \%$ & 76 & 74.5 \\
\hline$>25 \%$ & 26 & 25.5 \\
\hline
\end{tabular}


to deparaffinize, rehydrate and unmask the antigens the sections were boiled in Target Retrieval Solution buffer (pH 9; Dako) using Pre-Treament Link Platform (Dako) and, subsequently, cooled in a rinsing buffer (TBS). EnVision $^{\mathrm{TM}}$ FLEX (Dako) was used to visualize the antigens. Only in the case of VEGF-A IHC reaction, incubation with primary antibodies was extended from $20 \mathrm{~min}$ at RT to 18 hours at the temperature of $4^{\circ} \mathrm{C}$ and reaction was amplified using the EnVision ${ }^{\mathrm{TM}}$ FLEX + Mouse LINKER system (Dako).

Reactions with ER-specific antibodies (detecting estrogen receptors), PR-specific antibodies (detecting progesteron receptors) and with HER-2-specific antibodies were conducted according to the earlier described procedure [25]. The sections were deparaffinized and rehydrated in Antigen Retrieval Solution ( $\mathrm{pH}$ 6; Dako). Activity of endogenous peroxidase was blocked by 5 min incubation in $3 \% \mathrm{H}_{2} \mathrm{O}_{2}$. Subsequently, primary antibodies to ER (clone 1D5, 1:100) or PR (clone PgR 636, 1:100) and incubated for $1 \mathrm{~h}$ at RT. The subsequent reaction stages followed manufacturer's instructions for the LSAB + System-HRP visualization system (Dako). 3,3'-diaminobenzidine (DAB) was used as a chromogen. In order to visualize expression of HER2, the HercepTest ${ }^{\mathrm{TM}}$ kit (Dako) was used, according to the procedure recommended by the producer.

In order to examine the expression of VEGF-C, VEGF-D and Lyve-1, mouse antibodies anti-VEGF-C (2 $\mu \mathrm{g} / \mathrm{ml})$, antiVEGF-D $(2 \mu \mathrm{g} / \mathrm{ml})$ and anti-Lyve-1 $(1 \mu \mathrm{g} / \mathrm{ml})$ were used (ReliaTech GmbH, Braunschweig, Germany). The sections were deparaffinized in xylene, rehydrated and boiled in a citrate buffer, $\mathrm{pH} 6$ (for VEGF-C, Lyve-1) or $\mathrm{pH} 9$ (for VEGF-D). Subsequently, activity of endogenous peroxidase was blocked by 5 min incubation in $3 \% \mathrm{H}_{2} \mathrm{O}_{2}$. The sections were incubated with primary antibody overnight at the temperature of $4^{\circ} \mathrm{C}$ (VEGF-C, VEGF-D) or for $30 \mathrm{~min}$ at room temperature (Lyve-1). Then the antigens were visualized using the EnVision ${ }^{\mathrm{TM}}$ Detection Systems Peroxidase/DAB, Rabbit/Mouse (Dako).

All slides were counterstained with Mayer's hematoxylin (Dako). Subsequently, the preparations were mounted in SUB-X Mounting Medium (Dako).

\section{Evaluation of IHC Reactions}

In all cases hematoxylin-eosin $(\mathrm{H}+\mathrm{E})$ staining of the preparations was performed in order to determine grade of tumour $(G)$ and to evaluate the extent of necrosis in the tumours.

The intensity of IHC reactions for AT-1R, VEGF-A, VEGF-C and VEGF-D was estimated using the semiquantitative immunoreactive (IRS) scale of Remmele and Stegner [26]. Determination of Ki-67 antigen expression employed a five grade scale, reflecting percentage of tumour cells manifesting a nuclear reaction: $0 \%-0,1-10 \%-1,11-$ $25 \%-2,26-50 \%-3,51-100 \%-4$. For quantification of blood vessel and lymphatic vessel densities in the tumour and in the peritumoural area $\left(\mathrm{CD} 31^{+}\right.$, Lyve- $1^{+}$and D2-40 $)$ Chalkley point array (Pyser Sgi., Edenbridge, UK) was used. Under magnification of 200x, the vessels were scored in three intratumoural and peritumoural areas of potentially the highest density (hot spots). All the preparations were examined using OLYMPUS BX-41 light microscope (Olympus, Tokyo, Japan).

\section{Statistical Analysis}

The results were subjected to statistical analysis using Prism 5.0 (GraphPad, CA, USA). Relationships between expression of studied markers and clinicopathological factors were examined using the Spearman rank correlation test, the Kruskal-Wallis test and the exact Fisher's test. KaplanMeier's survival curves for the patients survival were analysed using the test of Mantel Cox. The differences were regarded significant at $p<0.05$.

\section{Results}

Expression of AT-1R in Ductal Breast Cancer and its Correlation with Clinical and Pathological Data

In most cases $(101 ; 99.1 \%)$ cytoplasmic expression of AT$1 \mathrm{R}$ was noted. Among them, 28 (27.5\%) cases demonstrated low expression of AT-1R (IRS 0-4) (Fig. 1a), while 74 $(72.5 \%)$ cases manifested moderate or high expression of AT-1R (IRS 6-12) (Fig 1b). Expression of AT-1R was detected also in the cells of tumour stroma. No significant differences were disclosed in AT-1R expression, which would be related to degree of the tumour malignancy. Expression of AT-1R failed to correlate with patients' age, tumour size or presence of metastases to lymph nodes, with expressions of ER, PR or expression of HER2 receptor (Table 2). Expression of AT-1R did not correlate with expression of Ki-67 proliferation antigen (Sperman's rank correlation test, $p=0.85$ ).

Correlation Between AT-1R Expression and Markers of Angiogenesis and Lymphangiogenesis

All the studied vascular endothelial growth factors (VEGF-A, VEGF-C and VEGF-D) manifested a cytoplasmic reaction in tumour cells. A pronounced expression of VEGF-A was noted in $52(51 \%)$, of VEGF-C in $56(54.9 \%)$, and of VEGF-D in 48 (47.1\%) studied cases. A moderately positive correlation was documented between expression of AT-1R on one hand and 


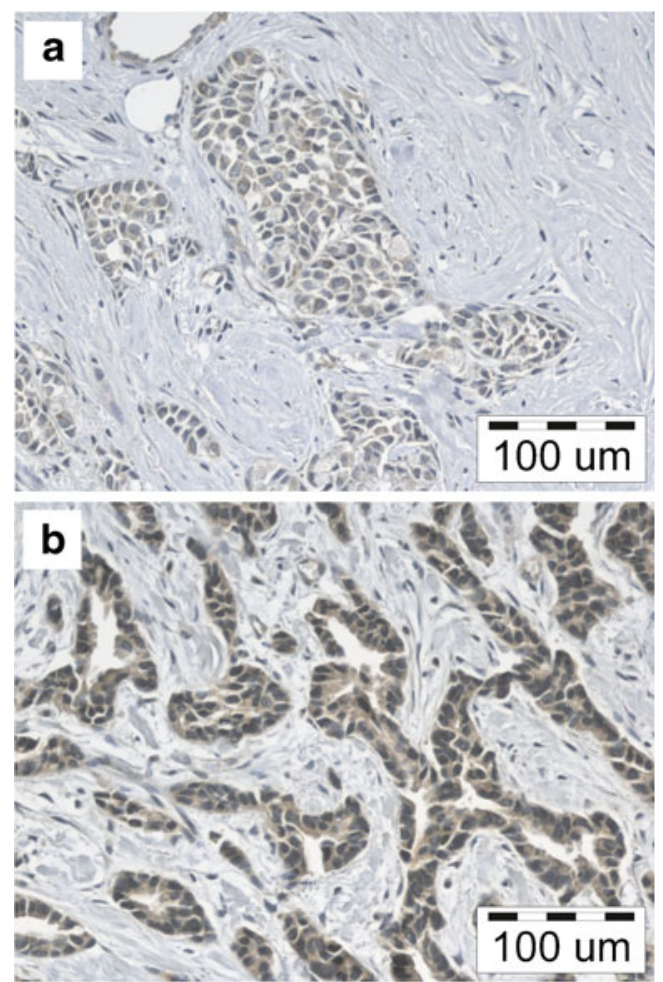

Fig. 1 IDC cases with low (a) or high (b) expression of AT-1R. Magnification 200x

expression of VEGF-A $(r=0.26, p=0.008)$ and VEGF-D expression $(r=0.24, p=0.015)$ on the other (Table 3 ).

No correlation was disclosed between the density of CD $31^{+}$ blood vessels expressed intra- and peritumorally and the intensity of AT-1R expression. Also no relationship could be disclosed between the intensity of AT-1R expression and the density of Lyve- $1^{+}$and D2-40 ${ }^{+}$lymphatic vessels (Table 4).

\section{Effect of AT-1R Expression on Patients' Outcome}

No significant differences were noted in patients survival regarding the intensity of AT-1R expression (Fig. 2a). The variables which significantly affected duration of patients' survival were primary tumour size $(\mathrm{pT})(p=0.028)$, presence of lymph nodes metastases $(\mathrm{pN})(p=0.0005)$ and high intensity of VEGF-C expression $(p=0.009$ ) (Figs. 2b-d, respectively).

\section{Discussion}

Results of earlier studies showed that the function of RAS system is not restricted exclusively to processes controlling body ions turnover but it may play a significant role in processes of proliferation, apoptosis and cell differentiation and significantly affect angiogenesis in neoplastic tumours [27]. Apart from function of the systemic RAS system,
Table 2 Correlation between AT-1R expression and selected clinical and pathological parameters

\begin{tabular}{|c|c|c|c|c|}
\hline \multirow[t]{2}{*}{ Variable } & \multirow[t]{2}{*}{ Number of cases (\%) } & \multicolumn{2}{|c|}{ AT-1R-number $(\%)$} & \multirow[t]{2}{*}{$p$} \\
\hline & & IRS $0-4$ & IRS 6-12 & \\
\hline \multicolumn{5}{|l|}{ Age } \\
\hline$\leq 50$ & $35(34.3)$ & $14(40.0)$ & $21(60.0)$ & 0.0601 \\
\hline$>50$ & $67(65.7)$ & $14(20.9)$ & $53(79.1)$ & \\
\hline \multicolumn{5}{|c|}{ Menopause } \\
\hline Pre & $38(31.3)$ & $13(34.2)$ & $25(63.8)$ & 0.2588 \\
\hline Post & $64(68.7)$ & $15(23.5)$ & $49(76.5)$ & \\
\hline \multicolumn{5}{|l|}{$\mathrm{pT}$} \\
\hline$\leq 2 \mathrm{~cm}$ & $64(62.7)$ & $19(29.7)$ & $45(70.3)$ & 0.6473 \\
\hline$>2 \mathrm{~cm}$ & $38(37.3)$ & $9(23.6)$ & $29(76.4)$ & \\
\hline \multicolumn{5}{|l|}{$\mathrm{pN}$} \\
\hline pN0 & $52(51.0)$ & $14(26.9)$ & $38(73.1)$ & 1.0000 \\
\hline $\mathrm{pN} 1-3$ & $50(49.0)$ & $14(28.0)$ & $36(72.0)$ & \\
\hline \multicolumn{5}{|l|}{ ER } \\
\hline Positive & $81(79.4)$ & $22(27.1)$ & $59(72.9)$ & 1.0000 \\
\hline Negative & $21(20.6)$ & $6(28.6)$ & $15(71.4)$ & \\
\hline \multicolumn{5}{|l|}{ PR } \\
\hline Positive & $68(66.7)$ & $20(29.4)$ & $48(70.6)$ & 0.6404 \\
\hline Negative & $34(33.3)$ & $8(23.5)$ & $26(76.5)$ & \\
\hline \multicolumn{5}{|l|}{ HER 2} \\
\hline Positive & $15(14.7)$ & $3(20.0)$ & $12(80.0)$ & 0.7547 \\
\hline Negative & $87(85.3)$ & $62(71.2)$ & $15(13.8)$ & \\
\hline
\end{tabular}

activities of a local RAS system have been demonstrated in several types of normal and neoplastic tissues, including tissues and cancers of the breast $[8,15]$. Moreover, in malignant lesions an increased AT-1R mRNA expression was demonstrated, as compared to healthy cells of mammary gland [4]. However, a decreased expression of AT-1R protein was detected by some authors in mammary cancers [28]. In turn, studies of Puddefoot et al. demonstrated increased metastatic potential of breast cancer cells dependent on integrin expression changes due to Ang II stimulation [18]. Ang II was also shown to promote cell proliferation by binding to AT-1R, by the activation of the phosphokinase $\mathrm{C}$ (PKC), what resulted in calcium ions mobilization [7, 28]. In addition, a stimulatory effect of Ang II on expression of VEGF-A was demonstrated exclusively in triple negative

Table 3 Correlation between AT-1R expression and expression of vascular endothelial growth factors (VEGF). Bold numbers indicate a significant correlation

\begin{tabular}{lll}
\hline VEGF & $\mathrm{r}$ & $p$ \\
\hline VEGF-A & $\mathbf{0 . 2 6}$ & $\mathbf{0 . 0 0 8}$ \\
VEGF-C & 0.09 & 0.356 \\
VEGF-D & $\mathbf{0 . 2 4}$ & $\mathbf{0 . 0 1 5}$ \\
\hline
\end{tabular}


Table 4 Correlation between AT-1R expression and selected markers of vascular density (CD31, Lyve-1, D2-40)

\begin{tabular}{|c|c|c|c|c|}
\hline \multirow[t]{2}{*}{ Marker } & \multirow[t]{2}{*}{ Number of cases $(\%)$} & \multicolumn{2}{|c|}{ AT-1R—Number (\%) } & \multirow[t]{2}{*}{$p$} \\
\hline & & IRS 0-4 & IRS 6-12 & \\
\hline \multicolumn{5}{|c|}{ CD31 Intra } \\
\hline$\leq 4$ & $24(23.5)$ & $8(33.3)$ & $16(66.7)$ & \multirow[t]{2}{*}{0.4475} \\
\hline$>4$ & $78(76.5)$ & $20(25.6)$ & $58(74.4)$ & \\
\hline \multicolumn{5}{|c|}{ CD31 Peri } \\
\hline$\leq 6$ & $44(43.1)$ & $14(31.8)$ & $30(68.2)$ & \multirow[t]{2}{*}{0.5021} \\
\hline$>6$ & $58(56.9)$ & $14(24.1)$ & $44(75.9)$ & \\
\hline \multicolumn{5}{|c|}{ Lyve-1 Intra } \\
\hline$\leq 1$ & $96(94.1)$ & $27(28.1)$ & $69(71.9)$ & \multirow[t]{2}{*}{0.3773} \\
\hline$>1$ & $6(5.9)$ & $1(16.7)$ & $5(83.3)$ & \\
\hline \multicolumn{5}{|c|}{ Lyve-1 Peri } \\
\hline$\leq 4$ & $77(75.5)$ & $19(24.7)$ & $58(75.3)$ & \multirow[t]{2}{*}{0.3068} \\
\hline$>4$ & $25(24.5)$ & $19(76.0)$ & $6(14.0)$ & \\
\hline \multicolumn{5}{|c|}{ D2-40 Intra } \\
\hline$\leq 2$ & $51(50.0)$ & $11(21.6)$ & $40(78.4)$ & \multirow[t]{2}{*}{0.2676} \\
\hline$>2$ & $51(50.0)$ & $17(33.3)$ & $34(66.7)$ & \\
\hline \multicolumn{5}{|c|}{ D2-40 Peri } \\
\hline$\leq 4$ & $52(51.0)$ & $12(23.1)$ & $40(76.9)$ & \multirow[t]{2}{*}{0.3733} \\
\hline$>4$ & $50(49.0)$ & $16(32.0)$ & $34(68.0)$ & \\
\hline
\end{tabular}

Intra-intratumoural vessels, Peri-peritumoural vessels

breast cancer (with no expression of ER, PR, HER2), but not on other breast cancer cell lines [19].

Results of our IHC investigations have documented a positive correlation of AT-1R expression intensity with the intensity of VEGF-A expression, corroborating earlier results obtained on other tumours with use of AT-1R blockers, which inhibited growth of tumour cells [20, 27, 29-33]. We have demonstrated also a positive correlation between AT-1R expression and intensity of VEGF-D expression. Earlier results related to the role of VEGF-D expression in neoplastic progression frequently yielded equivocal results [34-36]. According to Gu et al., increased expression of VEGF-D in breast cancer cells correlated with the development of metastases to lymph nodes and patients shorter survival [34]. On the other hand, studies of Gisterek et al., Mohammad et al. and Mylon et al. did not demonstrate any unfavourable effect of VEGF-D expression on patients' survival [35, 37, 38]. Moreover, the results of studies investigating the relationship between expression of VEGF-D and the density of lymphatic vessels were contradictory [34-36]. In our study, similarly to the results of Mohammad et al. and Gisterek et al., an increase in VEGF-D expression has not correlated with patients shorter survival, whereas a more pronounced expression of VEGF-C was associated with patients poor clinical outcome, confirming earlier reports $[35,38]$.

No relationship has been documented between the intensity of AT-1R expression and densities of blood and lymphatic vessels (both within the tumour and in the peritumoral area), although a positive correlation has been noted between AT-1R expression and intensities of VEGF-A and VEGF-D expression. Earlier studies of Herr et al. performed on clinical material of breast cancer and on two cellular models of the tumour suggested that Ang II might stimulate production of proangiogenic factors only in cases of triple negative breast cancers [19]. Many controversies have been noted on positive effects of intraepithelial growth factors on processes of angiogenesis and lymphangiogenesis, since the studies were performed on
Fig. 2 Kaplan-Meier's diagram of survival for 102 patients, as related to intensity of AT-1R expression (a), primary tumour size (b), presence lymph node metastases (c) and intensity of VEGF-C expression (d)
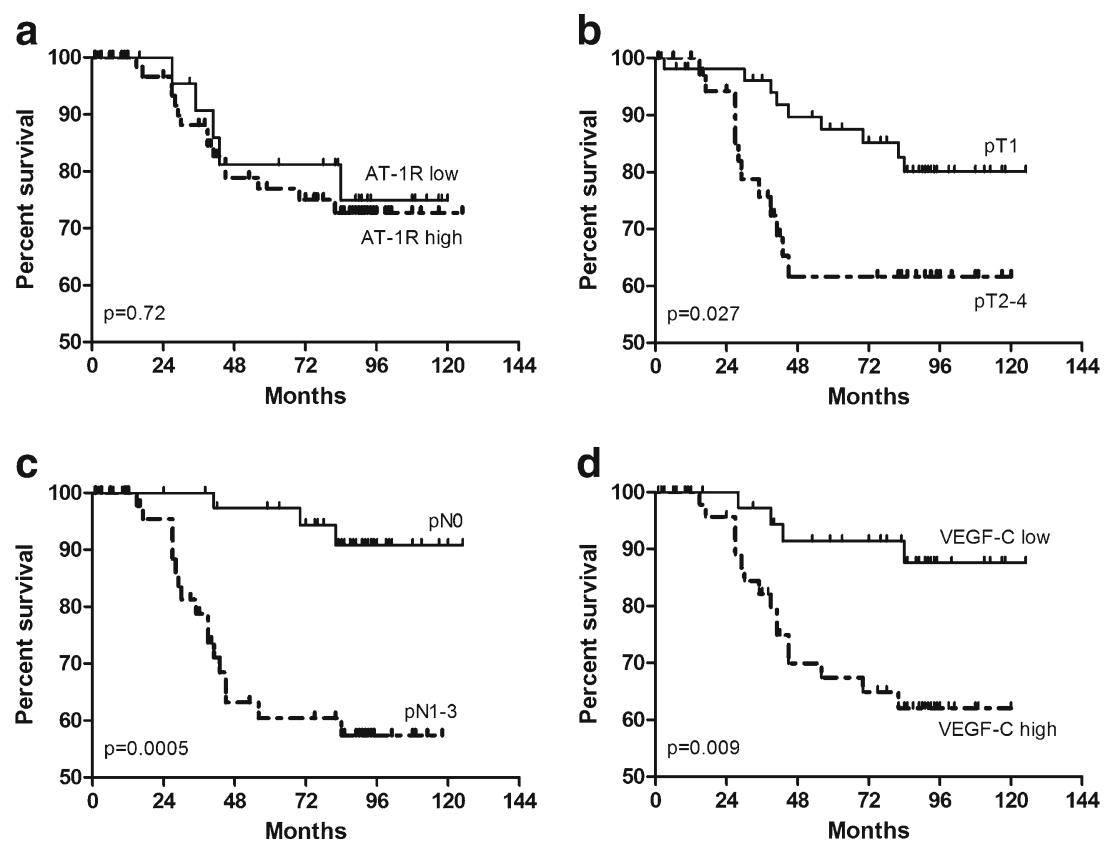
animals and frequently could not be reproduced on the clinical material of ductal breast cancer [39]. Moreover, angiogenic processes are influenced not only by tumour cells but also by tumour-associated fibroblasts and macrophages [40-42].

Our studies have demonstrated no relationship between intensity of AT-1R expression and some clinicopathological parameters, i.e. grade of malignancy, primary tumour size, presence of lymph node metastases, menopausal status or expression of ER, PR and HER2 receptors. In addition, statistical analysis has documented no effects of AT-1R expression intensity on survival of the patients.

Although our results have documented no relationships between AT-1R expression intensity and the listed clinicopathological parameters, in our opinion studies on the role of RAS in development of breast cancer should be continued, taking into account all proteins composing the system. Aside from our results, such a conclusion stems also from recent reports suggesting significant effects of an imbalance between activities of angiotensin-converting enzymes (ACE and ACE2) in the development of breast cancer [43]. This hypothesis was confirmed by studies demonstrating a marked increase in incidence of breast cancer in women carrying $\mathrm{D} / \mathrm{D}$ allele of the $A C E$ gene, which is linked to higher levels of the circulating ACE isoform in blood of these patients $[44,45]$. In addition, our results have confirmed effect of AT-1R on expression of VEGF-A. We have detected also a positive correlation between intensities of AT-1R expression and VEGF-D expression in IDC, which may have significance in better understanding the processes of lymphangiogenesis in IDC.

Acknowledgments The investigations were conducted within the research project of the Polish Ministry of Science and Higher Education: Significance of angiotensin II receptor, AT1 and AT2, expression and of lympho- and angiogenesis markers in breast cancers-N N401 217134.

Open Access This article is distributed under the terms of the Creative Commons Attribution License which permits any use, distribution, and reproduction in any medium, provided the original author(s) and the source are credited.

\section{References}

1. Ferlay J, Shin H-R, Bray F, Forman D, Mathers C, Parkin DM (2010) Estimates of worldwide burden of cancer in 2008: GLOBOCAN 2008. Int J Cancer 127:2893-2917

2. Cuzick J (2010) Breast cancer prevention in the developing world. Breast Cancer Res 12:S9

3. Chappell M (2010) Angiotensin-converting enzyme 2 autoantibodies: further evidence for a role of the renin-angiotensin system in inflammation. Arthritis Res Ther 12:128

4. De Paepe B, Verstraeten VL, De Potter CR, Vakaet LA, Bullock GR (2001) Growth stimulatory angiotensin II type-1 receptor is upregulated in breast hyperplasia and in situ carcinoma but not in invasive carcinoma. Histochem Cell Biol 116:247-254
5. De Gasparo M, Catt KJ, Inagami T, Wright JW, Unger T (2000) International union of pharmacology. XXIII. The angiotensin II receptors. Pharmacol Rev 52:415-472

6. Gwathmey TM, Shaltout HA, Pendergrass KD, Pirro NT, Figueroa JP, Rose JC, Diz DI, Chappell MC (2009) Nuclear angiotensin II type 2 (AT2) receptors are functionally linked to nitric oxide production. Am J Physiol Renal Physiol 296:1484-1493

7. Muscella A, Greco S, Elia MG, Storelli C, Marsigliante S (2002) Angiotensin II stimulation of $\mathrm{Na}+/ \mathrm{K}+$ ATPase activity and cell growth by calcium-independent pathway in MCF-7 breast cancer cells. J Endocrinol 173:315-323

8. Tahmasebi M, Barker S, Puddefoot JR, Vinson GP (2006) Localisation of renin-angiotensin system (RAS) components in breast. Br J Cancer 95:67-74

9. Steckelings UM, Kaschina E, Unger T (2005) The AT2 receptora matter of love and hate. Peptides 26:1401-1409

10. Bonnet F, Cao Z, Cooper ME (2001) Apoptosis and angiotensin II: yet another renal regulatory system? Exp Nephrol 9:295-300

11. Deshayes F, Nahmias C (2005) Angiotensin receptors: a new role in cancer? Trends Endocrinol Metabol 16:293-299

12. Fujimoto Y, Sasaki T, Tsuchida A, Chayama K (2001) Angiotensin II type 1 receptor expression in human pancreatic cancer and growth inhibition by angiotensin II type 1 receptor antagonist. FEBS Letters 495:197-200

13. Goldfarb DA, Diz DI, Tubbs RR, Ferrario CM, Novick AC (1994) Angiotensin II receptor subtypes in the human renal cortex and renal cell carcinoma. J Urol 151:208-213

14. Batra VK, Gopalakrishnan V, McNeill JR, Hickie RA (1994) Angiotensin II elevates cytosolic free calcium in human lung adenocarcinoma cells via activation of AT1 receptors. Cancer Lett $76: 19-24$

15. Inwang ER, Puddefoot JR, Brown CL, Goode AW, Marsigliante S, Ho MM, Payne JG, Vinson GP (1997) Angiotensin II type 1 receptor expression in human breast tissues. Br J Cancer 75:12791283

16. Greco S, Elia MG, Muscella A, Storelli C, Marsigliante S (2002) AT1 angiotensin II receptor mediates intracellular calcium mobilization in normal and cancerous breast cells in primary culture. Cell Calcium 32:1-10

17. Suzuki Y, Ruiz-Ortega M, Lorenzo O, Ruperez M, Esteban V, Egido J (2003) Inflammation and angiotensin II. Int J Biochem Cell Biol 35:881-900

18. Puddefoot JR, Udeozo UK, Barker S, Vinson GP (2006) The role of angiotensin II in the regulation of breast cancer cell adhesion and invasion. Endocr Relat Cancer 13:895-903

19. Herr D, Rodewald M, Fraser HM, Hack G, Konrad R, Kreienberg R, Wulff C (2008) Potential role of Renin-Angiotensin-system for tumor angiogenesis in receptor negative breast cancer. Gynecol Oncol 109:418-425

20. Suganuma T, Ino $K$, Shibata $K$, Kajiyama $H$, Nagasaka $T$, Mizutani S, Kikkawa F (2005) Functional expression of the angiotensin II type 1 receptor in human ovarian carcinoma cells and its blockade therapy resulting in suppression of tumor invasion, angiogenesis, and peritoneal dissemination. Clin Cancer Res 11:2686-2694

21. Khakoo AY, Sidman RL, Pasqualini R, Arap W (2008) Does the renin-angiotensin system participate in regulation of human vasculogenesis and angiogenesis? Cancer Res 68:91129115

22. Fox SB, Gasparini G, Harris AL (2001) Angiogenesis: pathological, prognostic, and growth-factor pathways and their link to trial design and anticancer drugs. Lancet Oncol 2:278-289

23. Imanishi T, Hano T, Nishio I (2004) Angiotensin II potentiates vascular endothelial growth factor-induced proliferation and network formation of endothelial progenitor cells. Hypertens Res 27:101-108 
24. Wasa J, Sugiura H, Kozawa E, Kohyama K, Yamada K, Taguchi O (2011) The tumor suppressive effect of angiotensin II type 1 receptor antagonist in a murine osteosarcoma model. Anticancer Res 31:123-127

25. Gomulkiewicz A, Podhorska-Okolow M, Szulc R, Smorag Z, Wojnar A, Zabel M, Dziegiel P (2010) Correlation between metallothionein (MT) expression and selected prognostic factors in ductal breast cancers. Folia Histochem Cytobiol 48:242-248

26. Remmele W, Stegner HE (1987) Recommendation for uniform definition of an immunoreactive score (IRS) for immunohistochemical estrogen receptor detection (ER-ICA) in breast cancer tissue. Pathologe 8:138-40

27. Willis LM, El-Remessy AB, Somanath PR, Deremer DL, Fagan SC (2011) Angiotensin receptor blockers and angiogenesis: clinical and experimental evidence. Clin Sci 120:307-319

28. Greco S, Muscella A, Elia MG, Salvatore P, Storelli C, Marsigliante S (2002) Activation of angiotensin II type I receptor promotes protein kinase $\mathrm{C}$ translocation and cell proliferation in human cultured breast epithelial cells. J Endocrinol 174:205-214

29. Rhodes DR, Ateeq B, Cao Q, Tomlins SA, Mehra R, Laxman B, Kalyana-Sundaram S, Lonigro RJ, Helgeson BE, Bhojani MS, Rehemtulla A, Kleer CG, Hayes DF, Lucas PC, Varambally S, Chinnaiyan AM (2009) AGTR1 overexpression defines a subset of breast cancer and confers sensitivity to losartan, an AGTR1 antagonist. Proc Natl Acad Sci U S A 106:10284-10289

30. Kosugi M, Miyajima A, Kikuchi E, Kosaka T, Horiguchi Y, Murai M (2007) Effect of angiotensin II type 1 receptor antagonist on tumor growth and angiogenesis in a xenograft model of human bladder cancer. Human Cell 20:1-9

31. Imai N, Hashimoto T, Kihara M, Yoshida S, Kawana I, Yazawa T, Kitamura H, Umemura S (2006) Roles for host and tumor angiotensin II type 1 receptor in tumor growth and tumor-associated angiogenesis. Lab Invest 87:189-198

32. Fujita M, Hayashi I, Yamashina S, Fukamizu A, Itoman M, Majima M (2005) Angiotensin type 1a receptor signalingdependent induction of vascular endothelial growth factor in stroma is relevant to tumor-associated angiogenesis and tumor growth. Carcinogenesis 26:271-279

33. Noguchi R, Yoshiji H, Ikenaka Y, Namisaki T, Kitade M, Kaji K, Yoshii J, Yanase K, Yamazaki M, Tsujimoto T, Kawaratani H, Fukui H (2009) Synergistic inhibitory effect of gemcitabine and angiotensin type-1 receptor blocker, losartan, on murine pancreatic tumor growth via anti-angiogenic activities. Oncol Rep 22:355-360

34. Gu Y, Qi X, Guo S (2008) Lymphangiogenesis induced by VEGF$\mathrm{C}$ and VEGF-D promotes metastasis and a poor outcome in breast carcinoma: a retrospective study of 61 cases. Clin Exp Metastasis 25:717-725

35. Mohammed RAA, Green A, El-Shikh S, Paish EC, Ellis IO, Martin SG (2007) Prognostic significance of vascular endothelial cell growth factors $-\mathrm{A},-\mathrm{C}$ and $-\mathrm{D}$ in breast cancer and their relationship with angio- and lymphangiogenesis. $\mathrm{Br} \mathrm{J}$ Cancer 96:1092-1100

36. Mylona E, Nomikos A, Alexandrou P, Giannopoulou I, Keramopoulos A, Nakopoulou L (2007) Lymphatic and blood vessel morphometry in invasive breast carcinomas: relation with proliferation and VEGF-C and -D proteins expression. Histol Histopathol 22:825-835

37. Gisterek I, Matkowski R, Koźlak J, Duś D, Łacko A, Szelachowska J, Kornafel J (2007) Evaluation of prognostic value of VEGF-C and VEGF-D in breast cancer - 10 years follow-up analysis. Anticancer Res 27:2797-2802

38. Mylona E, Alexandrou P, Mpakali A, Giannopoulou I, Liapis G, Markaki S, Keramopoulos A, Nakopoulou L (2007) Clinicopathological and prognostic significance of vascular endothelial growth factors (VEGF)-C and -D and VEGF receptor 3 in invasive breast carcinoma. Eur J Surg Oncol 33:294-300

39. van der Schaft DWJ, Pauwels P, Hulsmans S, Zimmermann M, van de Poll-Franse LV, Griffioen AW (2007) Absence of lymphangiogenesis in ductal breast cancer at the primary tumor site. Cancer Lett 254:128-136

40. Orimo A, Gupta PB, Sgroi DC, Arenzana-Seisdedos F, Delaunay T, Naeem R, Carey VJ, Richardson AL, Weinberg RA (2005) Stromal fibroblasts present in invasive human breast carcinomas promote tumor growth and angiogenesis through elevated SDF-1/ CXCL12 secretion. Cell 121:335-348

41. Eubank TD, Roberts RD, Khan M, Curry JM, Nuovo GJ, Kuppusamy P, Marsh CB (2009) Granulocyte macrophage colony-stimulating factor inhibits breast cancer growth and metastasis by invoking an anti-angiogenic program in tumor-educated macrophages. Cancer Res 69:2133-2140

42. Joimel U, Gest C, Soria J, Pritchard LL, Alexandre J, Laurent M, Blot E, Cazin L, Vannier JP, Varin R, Li H, Soria C (2010) Stimulation of angiogenesis resulting from cooperation between macrophages and MDA-MB-231 breast cancer cells: proposed molecular mechanism and effect of tetrathiomolybdate. BMC Cancer 10:375

43. Lambert DW, Clarke NE, Turner AJ (2010) Not just angiotensinases: new roles for the angiotensin-converting enzymes. Cell Mol Life Sci 67:89-98

44. González-Zuloeta Ladd AM, Arias Vásquez A, Sayed-Tabatabaei FA, Coebergh JW, Hofman A, Njajou O, Stricker B, van Duijn C (2005) Angiotensin-converting enzyme gene insertion/deletion polymorphism and breast cancer risk. Cancer Epidemiol Biomarkers Prev 14:2143-2146

45. González-Zuloeta Ladd AM, Arias Vásquez A, Siemes C, Yazdanpanah M, Coebergh JW, Hofman A, Stricker BH, van Duijn CM (2007) Differential roles of angiotensinogen and angiotensin receptor type 1 polymorphisms in breast cancer risk. Breast Cancer Res Treat 10:299-304 